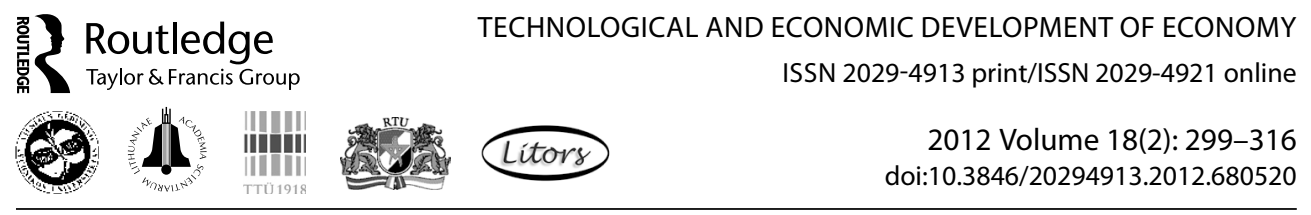

\title{
IMPROVED AHP-GROUP DECISION MAKING FOR INVESTMENT STRATEGY SELECTION
}

\author{
Wenshuai $\mathrm{Wu}^{1}$, Gang Kou${ }^{2}$, Yi Peng ${ }^{3}$, Daji Ergu ${ }^{4}$ \\ 1,2,3School of Management and Economics, University of Electronic Science and Technology of China, \\ 610054 Chengdu, China \\ ${ }^{4}$ Southwest University for Nationalities, 610200 Chengdu, China \\ E-mails: ${ }^{1}$ hhylwsw@163.com; ${ }^{2}$ kougang@yahoo.com (corresponding author); ${ }^{3}$ pengyicd@gmail.com; \\ ${ }^{4}$ ergudaji@163.com
}

Received 05 October 2011; accepted 10 March 2012

\begin{abstract}
Investment strategy selection relies heavily on personal experience and behavior. This paper proposes an improved Analytical Hierarchy Process-group decision making (IAHP-GDM) model to reduce investment risk. This model applies the method of least squares to adjust group decision matrix in order to satisfy the property of positive reciprocal matrix in AHP. In addition, five experts from related fields are invited to evaluate investment risk that takes group wisdom to eliminate personal bias. An empirical study is conducted to compare the proposed model to AHP for group decision making model. The results show that the IAHP-GDM model is not only accurate and effective, but also consistent with realistic investment environment.
\end{abstract}

Keywords: group decision making, Analytic Hierarchy Process, MCDM, investment management.

Reference to this paper should be made as follows: Wu, W.; Kou, G.; Peng, Y.; Ergu, D. 2012. Improved AHP-group decision making for investment strategy selection, Technological and Economic Development of Economy 18(2): 299-316.

JEL Classification: C44, C83, D81, G11.

\section{Introduction}

There are many risks in investment strategy selection, such as social risk, policy risk, economical risk, credit risk, technological risk, interest rate risk and operating risk (Kent 1992; Better et al. 2008; Gao et al. 2008; Li et al. 2009; Peng et al. 2009, 2010; Shen 2009; Liaudanskiené et al. 2010), contract's risks (Zavadskas et al. 2010; Boguslauskas et al. 2011). Shyng et al. 
(2010) suggest that past experiences of individuals usually affect their attitudes when they made investment decisions. In an attempt to make better investment decisions, many studies have been conducted to evaluate investment strategy and its risk (Metrick 1999; Bayraktar, Young 2010; Ba et al. 2011).

Over the past few decades, investment management has been an active research area (Barry, Starks 1984; Froot 1993; Jorion 2000; Malkiel 2003; Arljukova 2008; Binsbergen et al. 2008; Busse et al. 2010; Stoughton et al. 2011). From the investor's perspective, the decision process can be roughly divided into four components: problem recognition, information search, evaluation of alternatives and investment decision (Shyng et al. 2010; Keršulienè, Turskis 2011). The most important part is the evaluation of alternatives, which could create the best investment strategy for satisfying the investors' needs. The analytical hierarchy process (AHP) is often implemented in the risk evaluation to improve the effectiveness of investment management and decision analysis (Wijnmalen 2007). However, when establishing the judgment matrix by expert scoring, the AHP method is subjective, the evaluation result is not objective and sometimes different experts may reach different conclusions.

Consulting multiple experts reduces bias when the judgments are provided by a single expert (Ishizaka, Labib 2011). This paper proposes IAHP-GDM model for evaluation of investment alternatives, which not only overcomes the disadvantage of subjective decision, but also takes group wisdom to eliminate the bias generated by personal preferences. The method of Least squares (Cassel et al. 1999; Bozóki 2008; Yu et al. 2009) is introduced to revise group decision making matrix to become the positive reciprocal matrix.

The remaining part of this paper is organized as follows. Section 2 reviews the related works. Section 3 introduces some foundations of AHP and a previous proposed model: AHP for group decision making. Section 4 describes the IAHP-GDM model. In Section 5, an illustrative case of investment strategy selection is conducted to compare the IAHP-GDM model to the previous proposed AHP for group decision making model. Section 6 concludes the paper.

\section{Related works}

The AHP was introduced by Saaty in 1970s, and has been identified as an important method to solve multi-criteria decision-making problems of choice and prioritization (Satty 1978, $1979,1980,1986,2003,2006)$. AHP has been applied to solve many types of decision problems (Wind, Saaty 1980; Handfield et al. 2002; Li, Ma 2008; Nieto-Morote, Ruz-Vila 2011; Peng et al. 2011a).

In AHP method, the calculated priorities are suitable only if the pair-wise comparison matrix passes the consistency test when the reciprocity rule is respected within the pair-wise comparison process (Ishizaka, Lusti 2004). The pair-wise comparison matrix is composed of elements presented in a numerical scale, which is provided by decision makers based on their experiences and expertise. Thereby, the pair-wise comparison matrix could be inconsistent due to the limitations of experiences and expertise as well as the complexity nature of decision problem (Ergu et al. 2011a). 
With the social development and technology advancement, decision-making process has also become more and more complex. It is often difficult to make a scientific and accurate decision-making only by single decision maker. The reasons are as follows (Kim, Ahn 1997):

1) A decision is usually made under time pressure, lack of knowledge and data cases.

2) Many of the attributes are difficult to quantify.

3) Single decision maker has limited expertise and information processing capacity, especially in complex and uncertain environment.

4) In group setting, all participants do not have equal expertise about the same problem. Their views can hardly be uniformed. Therefore, in order to reduce the decision-making mistakes, many important decisions are made by multiple decision makers, especially in companies or organizations.

Many researchers consider the AHP method to be well suited for group decision making due to its role as a synthesizing mechanism (Dyer, Forman 1992; Bard, Sousk 1990), where group members can use their experience and expertise to break down a problem into a hierarchy and solve it by the AHP steps (Kamal, Al-Subhi 2001). However, group decisions involving participants with common interests are typical of many organizational decisions (Alfares, Duffuaa 2008; Kamal, Al-Subhi 2001; Rao, Peng 2009; Wei, Tang 2011). There are four ways to combine the preferences into a consensus rating showed in the Table 1 (Ishizaka, Labib 2011).

Table 1. Four ways to combine preferences (Ishizaka, Labib 2011)

\begin{tabular}{|c|c|c|c|}
\hline & & \multicolumn{2}{|c|}{ Mathematical aggregation } \\
\hline & & Yes & No \\
\hline \multirow[t]{2}{*}{ Aggregation on } & Judgments & $\begin{array}{l}\text { Geometric mean on } \\
\text { judgments }\end{array}$ & $\begin{array}{l}\text { Consensus vote on } \\
\text { judgments }\end{array}$ \\
\hline & Priorities & $\begin{array}{l}\text { Weighted arithmetic } \\
\text { mean on priorities }\end{array}$ & $\begin{array}{c}\text { Consensus vote on } \\
\text { priorities }\end{array}$ \\
\hline
\end{tabular}

There are a few studies in AHP integrated the group decision-making. Korpela and Tuominen have applied this method to assess the applicability of the AHP in defining the goals of distribution logistics (Korpela, Tuominen 1997) and to analysis the project's logistics department in group settings (Korpela, Tuominen 1995). Dyer and Forman (1992) argued that AHP can help group decision-makers structure complex decisions, and synthesize measures of both tangibles and intangibles. However, the pair-wise comparison matrix could be inconsistent due to the limitations of experiences and expertise.

\section{Preliminaries}

Multi-criteria decision making (MCDM) method is a decision-making analysis method, which has been developed since 1970s. MCDM is the study of methods which concerns about multiple conflicting criteria (Choi, Woo 2011; Peng et al. 2011b; Soylu 2010; Kou et al. 2012). In the following sub-sections, we present the concepts of AHP, one of the widely used MCDM methods, and introduce AHP for group decision making method presented by Wu et al. (2011). 


\subsection{AHP}

The analytic hierarchy process (AHP) proposed by Saaty (1980) is a widely used decision making analysis tool for modeling unstructured problems in political, economic, social, and management sciences (Levary, Wan 1998; Chang 1996; Tupenaite et al. 2010; Lin 2010; Cheng et al. 2011; Ergu et al. 2011b; Wu et al. 2010; Medineckienè, Björk 2011). Pair-wise comparison is an important part in AHP, completed by the experts (Kamal, Al-Subhi 2001; Liu, Shih 2005). Based on the pair-by-pair comparison values for a set of objects, AHP is applied to elicit a corresponding priority vector that represents preferences (Yu 2002).

\subsection{AHP for group decision making}

Analytic hierarchy process (AHP) for group decision-making model is applied to determine the index weight presented by Wu et al. (2011). There are three steps. First, the original index weight of each expert is calculated by applying AHP. Second, each expert weight is determined for group decision making. Finally, the index weight is obtained by considering each expert weight. Based on the size of criteria weight, AHP for group decision making is used to elicit the corresponding alternative priorities.

\subsubsection{Determine original index weight}

AHP is a decision-aiding method developed by Saaty $(1985,1990)$, Saaty, Zoffer (2011) to quantify relative priorities for a given set of alternatives on a ratio scale, based on the judgment of the decision-maker, and stress the importance of the intuitive judgments of a decision maker as well as the consistency of the comparison of alternatives in the decisionmaking process (Saaty 1980). The AHP approach has recently become popular in assessing criteria weights in various multi-criteria decision making problems. It elicits a corresponding priority vector interpreting the preferred information from the decision makers, based on the pair-wise comparison values of a set of objects. Since pair-wise comparison values are the judgments obtained from an appropriate semantic scale. AHP method is applied to determine original index weight.

\subsubsection{Determine expert weight for group decision-making}

AHP allows group decision making, where group members can use their experience and expertise to break down a problem into a hierarchy and solve it by the AHP steps (Kamal, Al-Subhi 2001). Since different experts have different criteria preferences, it is essential to give a certain weight for each expert. Assume there are $n$ experts for group decision making.

First, we determine the pair-wise comparison matrix $A=\left(a_{i j}\right)_{m \times m}$, and the corresponding consistency ratio $C R_{k}^{t}$ is obtained by AHP, $t(1 \leq t \leq T)$ is the number of pair-wise matrix in AHP determined by each expert, $k(1 \leq k \leq n)$ is the number of the experts. Then, the $k^{t h}$ expert weight $P_{k}$ can be calculated by the following formula:

$$
P_{k}^{t}=\frac{1}{1+\alpha C R_{k}^{t}}(\alpha>0,1 \leq k \leq n, 1 \leq t \leq T) .
$$




$$
P_{k}=\frac{\sum_{t=1}^{T} P_{k}^{t}}{T}(1 \leq k \leq n, 1 \leq t \leq T) .
$$

When the parameter value $\alpha$ is too large or too small, the expert weight is usually difficult to be distinguished. In practice, the value of $\alpha$ is usually set to 10 , to offer moderate distinguishing effects and good stability. Finally, the expert weight $P_{k}^{*}$ can be obtained by normalizing formula (2) as follows:

$$
P_{k}^{*}=\frac{p_{k}}{\sum_{k=1}^{n} P_{k}}(1 \leq k \leq n) .
$$

\subsubsection{Determine final index weight}

The final index weight is determined based on original index weight $W_{i}^{k}(1 \leq i \leq m)$ by AHP, and considered of expert weight $P_{k}^{*}$. This paper firstly applies AHP to get the original index weight $W_{i}^{k}$, and then takes expert weight $P^{*}$ in group decision-making into account. The final index weight can be calculated as:

$$
W_{i}=\sum_{k=1}^{n} W_{i}^{k} \cdot P_{k}^{*} \quad(1 \leq k \leq n, 1 \leq i \leq m) .
$$

Finally, the index weight $W_{i}^{*}$ of the $i^{\text {th }}$ index can be normalized:

$$
W_{i}^{*}=\frac{W_{i}}{\sum_{i=1}^{m} W_{i}}(1 \leq i \leq m) .
$$

When calculating the final index weight, the revised AHP introduces a number of experts to evaluate index weight in order to avoid different decision-making preferences by experts. This method introduces less subject judgment in decision matrix by combining the opinions of different experts.

\section{Proposed model: IAHP-GDM}

In the process of traditional AHP method, the key step is to determine the hierarchy structure in order to achieve the criteria weights, and in general, the matrix is determined by expert scoring. Because comparison matrix is one of the most important parts in AHP, there exist many studies in comparison matrix (Carmone et al. 1997; Fedrizzi, Giove 2007; Cao et al. 2008; Ergu et al. 2011c). The pair-wise comparison values are the judgments obtained by a suitable semantic scale. Therefore it is unrealistic to expect that the decision makers have either complete information or a full understanding of all aspects of the problem (Chang 1996; Levary, Wan 1998; Ergu et al. 2011b). In this paper, based on the previous research, we consider the views of multi-experts, and propose an IAHP-GDM model. In order to improve 
the evaluation accuracy away from the expert's subjective preferences as much as possible, we invite five experts from related fields to judge, and make the comprehensive analysis on the comparison matrix of each expert. In addition, when constructing the group decision making matrix, there is usually a disadvantage that the positive reciprocal property is not satisfied. Thereby, in this paper, the method of least squares (Bozóki, Lewis 2005; Liu et al. 2011) is further applied to improve group decision making matrix which makes the matrix satisfy positive reciprocal property. The steps are as follows:

1) Judge the relative importance of pair-wise indicators to the target in terms of expert scoring. Assume there are $\mathrm{k}(1 \leq k \leq n)$ experts, two indicators $\mathrm{a}$, and $\mathrm{b}$. The corresponding scores provided by expert $k_{1}$ are $r_{1}$ and $r_{2}$, respectively. Then the relative importance of a is $a_{k_{1}}=\frac{r_{1}}{r_{2}}$, and the relative importance of $\mathrm{b}$ is $b_{k_{1}}=\frac{r_{2}}{r_{1}}$.

2) Determine the overall relative importance of indicators to the targets. Since different experts have different knowledge, experiences, preference and so on, when calculating the overall relative importance of indicators to the targets, the maximum score and the minimum score should be removed. Therefore, the overall relative importance of indicator $a$ and $b$ to the target are $\frac{1}{m-2} \sum_{i=1}^{m-2} a_{k_{i}}(1 \leq i \leq m)$ and $\frac{1}{m-2} \sum_{i=1}^{m-2} b_{k_{i}}(1 \leq i \leq m)$ respectively.

3) Determine group decision making matrix according to the overall relative importance of each indicator to the target. This method to determine the group decision making matrix improves the accuracy and scientific level of AHP method.

4) Optimize group decision making matrix based on the method of least squares. Assume $\mathrm{k}$ experts give $A_{1}, \cdots A_{k}$ comparison matrices respectively. It is easy to know that each $A_{k}(1 \leq k \leq n)$ is positive reciprocal matrix. Let $\lambda_{l}(1 \leq l \leq n)$ be the weight coefficient of each expert, and it is a comprehensive quantitative indicator measuring expert's ability level. Assume each expert weight is the same, which is $\frac{1}{n}$. Then, gather all pair-wise comparison matrices provided by each expert to get group decision making comparison matrix $B=\left(\lambda_{1} A_{1}+\lambda_{2} A_{2}+\cdots \lambda_{n} A_{n}\right)=\left(b_{i j}\right)_{m \times m}$, it is obvious to get $b_{i j}=\sum_{k=1}^{n} \lambda_{i} a_{i j}^{(k)}(1 \leq i \leq m, 1 \leq j \leq m, 1 \leq k \leq n)$.

It is easy to get that matrix B cannot meet the reciprocal property. In this article, the method of least square is applied to revise group decision making comparison matrix $\mathrm{B}$, and get another matrix $B^{*}$, which is very close to $B$ and meets the positive reciprocal property. The specific steps are as follows:

First of all, we get the least squares mathematical programming problems:

$$
\begin{aligned}
& \min \sum_{i=1}^{m} \sum_{j=1}^{m}\left(x_{i j}-b_{i j}\right)^{2} \\
& \text { s.t. }\left\{\begin{array}{l}
x_{i j} \times x_{j i}=1 \\
x_{i j}>0(1 \leq i \leq m, 1 \leq j \leq m)
\end{array}\right\} .
\end{aligned}
$$


From the above characteristics of optimization problem of objective function, according to $x_{i j}=\frac{1}{x_{j i}}$, the question above can be changed into:

$$
\begin{aligned}
& \min \left\{\begin{array}{l}
\left(x_{12}-b_{12}\right)^{2}+\left(\frac{1}{x_{21}}-b_{21}\right)^{2}+\cdots+\left(x_{1 m}-b_{1 m}\right)^{2}+\left(\frac{1}{x_{m 1}}-b_{m 1}\right)^{2}+ \\
\cdots+\left(x_{m-1, m}-b_{m-1, m}\right)^{2}+\left(\frac{1}{x_{m, m-1}}-b_{m, m-1}\right)^{2}
\end{array}\right\} . \\
& \text { s.t. } x_{i j}>0(1 \leq i \leq m, 1 \leq j \leq m)
\end{aligned}
$$

By mathematical derivation, the above problem can be further broken down as sub-problems:

Let

$$
\begin{gathered}
\min \left\{\left(x_{i j}-b_{i j}\right)^{2}+\left(\frac{1}{x_{j i}}-b_{j i}\right)^{2}\right\} . \\
\text { s.t. } x_{i j}>0(1 \leq i \leq m, 1 \leq j \leq m)
\end{gathered}
$$

When $x_{i j} \rightarrow 0$ or $x_{i j} \rightarrow+\infty$, the minimum value of $f(x) \rightarrow+\infty$ must be the stagnation, therefore it should further to satisfy:

Finally, we can get:

$$
2\left(x_{i j}-b_{i j}\right)+2\left(\frac{1}{x_{i j}}-b_{j i}\right)\left(-\frac{1}{x_{i j}^{2}}\right)=0 .
$$

$$
x_{i j}^{4}-b_{i j} x_{i j}^{3}+b_{j i} x_{i j}-1=0 .
$$

Find out all its positive solution which makes $f(x)$ the minimum. The solving process can be completed by the MATLAB.

5) Determine the preference order of each alternative. The procedures are consistent with the traditional AHP method.

Above all, the steps of the improved AHP based on the method of least squares can be summarized as follows:

Step 1: Determine the original comparison matrix $A_{k}=\left(a_{i j}\right)_{m \times m}$ according to expert scoring.

Step 2: Determine the final overall relative importance between indicators to the targets. Step 3: Determine group decision making matrix $B=\sum_{k=1}^{n} \lambda_{k} A_{k}$ according to the final
overall relative importance of indicators to the targets.

Step 4: Determine the final group decision making comparison matrix by the method of least squares. According to the least squares mathematical programming function, for $1 \leq i \leq m, 1 \leq j \leq m$, find out all the positive solutions of $x_{i j}^{4}-b_{i j} x_{i j}^{3}+b_{j i} x_{i j}-1=0$ by MATLAB, and mark $b_{i j}^{*}$ which make the function $f(x)=\left(x-b_{i j}\right)^{2}+\left(\frac{1}{x}-b_{j i}\right)^{2}$ get minimum value. Let $b_{j i}^{*}=\frac{1}{b_{i j}^{*}}$, and it is easy to get $B^{*}=\left(b_{i j}^{*}\right)_{m \times m}$ which is a final group decision making comparison matrix and meets positive reciprocal matrix.

Step 5: Determine the preference order of each alternative according to the standard AHP steps. 


\section{Empirical studies}

In this section, an empirical study on investment strategy selection is displayed to illustrate the application of our proposed model for evaluating and selecting the best investment alternative of fund investment, bonds investment, stock investment, and real estate investment.

\subsection{Problem description}

As the number of alternative investment opportunities brought out, financial advisers have played a more and more prominent role in allocating assets and investment plan (Stoughton et al. 2011). And a well-made financial investment plan can help to achieve good asset allocation. The investment strategy selection is essential to decrease loss caused by risks and win better investment benefit. With regard to financial hardship, research suggests that the past experiences and expertise of individuals usually affect their attitudes towards making investments (Shyng et al. 2010). In this paper, we focus on identifying different types of information and criteria to select the best investment strategy which create more personalized investment alternative for satisfying the investors' needs. Thereby, IAHP-GDM model is proposed for evaluation of the investment alternative to select the best investment strategy.

\subsection{Decision hierarchy structure and index system}

There are many risk classifications in investment management, such as systemic risk, market risk, industry risk and so on. To evaluate the investment strategy, decision hierarchy structure and eight important criteria are determined by the experience and expertise of the expert team and by reviewing existing literatures (Teichroew et al. 1965; Davanzo, Nesbitt 1987; Fried, Hisrich 1994; Ginevičius, Zubrecovas 2009). The expert team is composed of five experts in the field of investment. And we select fund investment, bonds investment, stock investment and real estate investment as the assessment objects. The decision hierarchy structure is presented in Figure 1.

In Figure 1, there are four levels in the decision hierarchy structure for investment strategy selection. The overall goal of the decision process is determined as "Select best investment strategy: A". It is the first level of the hierarchy structure. The criteria level is the second level including "Profitability: B1" and "Security: B2", which is the standard measuring whether the target can be achieved. The third level is the sub-criteria level including eight criteria: "Investment opportunities: C1", "Liquidity: C2", "Prospect: C3", "Expected profit: C4", "Payback period: C5", “Transaction costs: C6", "Interest rate risk: C7" and "Credit risk: C8”. The final level of hierarchy structure, that is the fourth level, is investment alternative level including "Fund investment: D1", "Bonds investment: D2", "Stock investment: D3" and "Real estate investment: D4".

\subsection{Empirical analysis}

In this section, an empirical case is conducted to verify the proposed model in comparison with AHP for group decision making proposed by Wu et al. (2011). After conducting the decision hierarchy structure for solving investment problem, the pair-wise comparison matrix 


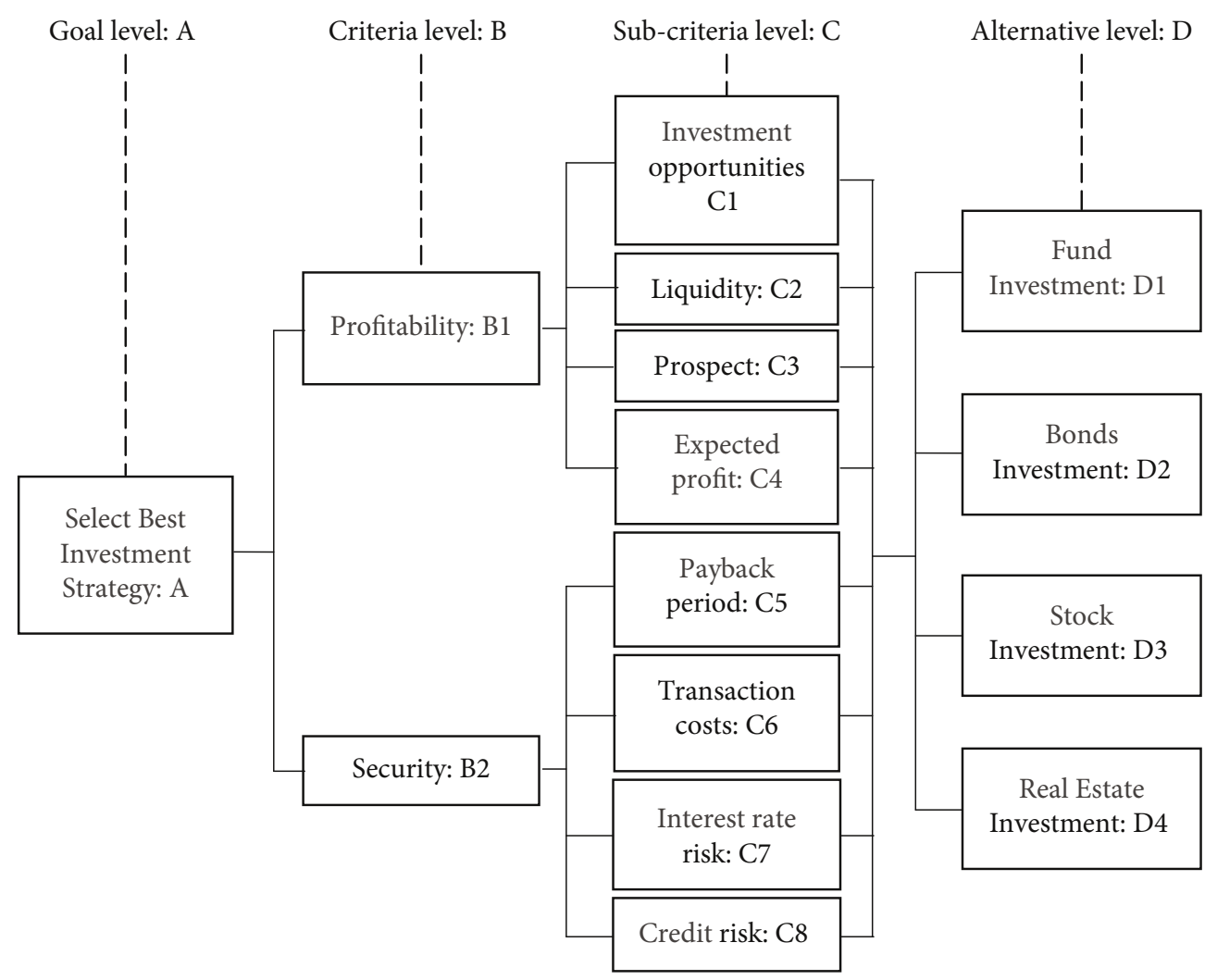

Fig. 1. The hierarchical structure of the decision making problem

used in evaluation process is calculated by the proposed model. In order to eliminate the bias generated by personal preferences, we consulted five experts to construct pair-wise comparison matrix by researching on investment market. And, the pair-ware comparison matrix is obtained by expert scoring, as shown in the Table 1-11 of Appendix. In the experiment, first of all, we introduce the current IAHP-GDM model for investment strategy selection. Then, the previous model (Wu et al. 2011) is applied as comparison analysis to illustrate that the proposed model in this paper is effective and efficient. The specific process is as follows:

First of all, the IAHP-GDM model is applied to select the best investment strategy for investment management. The evaluation process is as follows:

1) Determine group decision making comparison matrix according to the steps $1-3$. The group decision making matrix is the key step of the proposed model.

2) Determine the final group decision making comparison matrix revised by the method of Least squares according to the step 4. In addition, the criteria weight and consistency test are determined by the standard AHP steps.

3) Determine the preference order of each alternative according to step 5. The results are showed in Table 2. From Table 2, we can get that the real estate investment is the best investment strategy, followed by stock investment, fund investment, and bonds investment. 
Table 2. Alternative rank of IAHP-GDM model

\begin{tabular}{lcc}
\hline \multicolumn{1}{c}{ Investment Strategy } & Evaluation Value $(\mathrm{EV})$ & Rank \\
\hline Bonds Investment & 0.1399 & 4 \\
\hline Fund Investment & 0.1865 & 3 \\
\hline Stock Investment & 0.3095 & 2 \\
\hline Real Estate Investment & 0.3641 & 1 \\
\hline
\end{tabular}

Then, the previous model presented by Wu et al. (2011) is applied to determine the alternative rank by comparison to illustrate that the current proposed model is effective and efficient. There are three steps as follows:

1) Determine original index weight. The original index weight according to each expert is calculated by applying AHP.

2) Determine expert weight. Each expert weight for group decision making is determined by the formula in the Section 3.2.2. By calculating, the weight of five experts is obtained as $0.1960,0.2193,0.2090,0.1783$ and 0.1974 .

3) Determine alternative rank. The final index weight is obtained by considering each expert weight. According to the final index weight, alternative rank can be determined by the Section 3.2.3.

To illustrate which method is more effective, comparison analysis and difference degree analysis are applied for evaluation. The results are showed in the Table 3.

Table 3. Result comparison

\begin{tabular}{lcccccc}
\hline \multirow{2}{*}{ Investment Strategy } & \multicolumn{2}{c}{ AHP for group decision-making } & \multicolumn{3}{c}{ IAHP-GDM model } \\
\cline { 2 - 7 } & EV & Rank & DD & EV & Rank & DD \\
\hline Bonds Strategy & 0.1853 & 4 & $3.35 \%$ & 0.1399 & 4 & $33.31 \%$ \\
\hline Fund Strategy & 0.1915 & 3 & $53.00 \%$ & 0.1865 & 3 & $65.95 \%$ \\
\hline Stock Strategy & 0.2930 & 2 & $12.70 \%$ & 0.3095 & 2 & $17.64 \%$ \\
\hline Real Estate Strategy & 0.3302 & 1 & & 0.3641 & 1 & \\
\hline
\end{tabular}

EV: Evaluation Value; DD: Different Degree

In Table 3, the ranks of investment strategy of the two models are the same. The rank of real estate investment, stock investment, fund investment and bonds investment is 1, 2, 3,4 . The best investment strategy is real estate investment, followed by stock strategy, fund strategy, and the worst is bonds investment. The most effective investment strategy to achieve maximum profits is real estate investment. However, which method is better? Different degree analysis on investment strategy is further applied, as shown in the Table 3 . The calculation of the different degree can be obtained as follows: Assume there are two alternatives: A, and $\mathrm{B}$, the different degree of $\mathrm{A}$ and $\mathrm{B}$ alternatives is defined as:

$$
\text { different degree }=\frac{B E V-A E V}{A E V} \times 100 \%
$$


For example, the different degree of Bonds Strategy and Fund Strategy in IAHP-GDM model is calculated as follows:

$$
\text { different degree }=\frac{0.1865-0.1399}{0.1399} \times 100 \%=33.31 \% .
$$

From Table 3, we can see that different degrees obtained by IAHP-GDM are larger than those obtained by AHP for group decision-making model, which indicate that the proposed model is more accurate and effective than AHP for group decision-making model.

\section{Conclusion}

In an uncertain economic decision environment, investors face the unprecedented challenges and opportunities. In order to make the investment decision reduce loss caused by risks and achieve better investment benefit, this paper proposes an IAHP-GDM model for investment strategy selection. In this model, the maximum score and the minimum score are removed when group decision making is conducted to make the decision fair and justice. The method of least squares is applied to revise group decision making matrix to satisfy positive reciprocal property of AHP. In addition, five experts from related research field are invited to evaluate investment risk problem that takes group wisdom to eliminate the bias generated by personal preferences. An empirical study compares the proposed model to the previous research model. The results show the proposed model in this paper is more accurate and effective, and the research results are consistent with realistic investment environment. These findings support the view that this proposed model can offer good investment strategies for better investment management.

\section{Acknowledgements}

The authors are grateful to the reviewers for their valuable suggestions which helped in improving the quality of this paper. This research has been partially supported by grants from the National Natural Science Foundation of China (\#70901011 and \#71173028 for Yi Peng, \#70901015 and \#70921061 for Gang Kou), the Fundamental Research Funds for the Central Universities and Program for New Century Excellent Talents in University (NCET-10-0293).

\section{References}

Alfares, H. K.; Duffuaa, S. O. 2008. Determining aggregate criteria weights from criteria rankings by a group of decision makers, International Journal of Information Technology \& Decision Making 7(4): 769-781. http://dx.doi.org/10.1142/S0219622008003174

Arljukova, I. 2008. Problems preventing air companies from efficient investment activities, Technological and Economic Development of Economy 14(3):247-259. http://dx.doi.org/10.3846/1392-8619.2008.14.247-259

Ba, X.; Zhang, Y.; Wu, Y. N. 2011. An AHP grey evaluation model of the real estate investment risk, Computing and Intelligent Systems 234: 325-334. http://dx.doi.org/10.1007/978-3-642-24091-1_43 
Bard, J. F.; Sousk, S. F. 1990. A tradeoff analysis for rough terrain cargo handlers using the AHP: an example of group decision making, IEEE Transactions on Engineering Management 37(3): 222-227. http://dx.doi.org/10.1109/17.104292

Barry, C. B.; Starks, L. T. 1984. Investment management and risk sharing with multiple managers, The Journal of Finance 39(2): 477-491. http://dx.doi.org/10.2307/2327872

Bayraktar, E.; Young, V. R. 2010. Optimal investment strategy to minimize occupation time, Annals of Operations Research 176(1): 389-408. http://dx.doi.org/10.1007/s10479-008-0467-2

Better, M.; Glover, F.; Kochenberger, G.; Wang, H. 2008. Simulation optimization: applications in risk management, International Journal of Information Technology \& Decision Making 7(4): 571-587. http://dx.doi.org/10.1142/S0219622008003137

Binsbergen, V. J. H.; Brandt, M. W.; Koijen, R. S. J. 2008. Optimal decentralized investment management, The Journal of Finance 63(4): 1849-1895. http://dx.doi.org/10.1111/j.1540-6261.2008.01376.x

Boguslauskas, V.; Mileris, R.; Adlyte, R. 2011. New internal rating approach for credit risk assessment, Technological and Economic Development of Economy 17(2): 369-381. http://dx.doi.org/10.3846/20294913.2011.583721

Bozóki, S.; Lewis, R. H. 2005. Solving the Least Squares Method problem in the AHP for $3 \times 3$ and $4 \times 4$ matrices, Central European Journal of Operations Research 13(3): 255-270. http://dx.doi.org/10.1007/s10898-008-9303-0

Bozóki, S. 2008. Solution of the Least Squares Method problem of pairwise comparison matrices, Central European Journal of Operations Research 16: 345-358. http://dx.doi.org/10.1007/s10100-008-0063-1

Busse, J. A.; Goyal, A.; Wahal, S. 2010. Performance and persistence in institutional investment management, The Journal of Finance 65(2): 765-790. http://dx.doi.org/10.1111/j.1540-6261.2009.01550.x

Cao, D.; Leung, L. C.; Law, J. S. 2008. Modifying inconsistent comparison matrix in analytic hierarchy process: a heuristic approach, Decision Support System 44: 944-953. http://dx.doi.org/10.1016/j.dss.2007.11.002

Carmone, F. J.; Kara, A.; Zanakis, S. H. 1997. A Monte Carlo investigation of incomplete pair-wise comparison matrices in AHP, European Journal of Operational Research 102(3): 538-553. http://dx.doi.org/10.1016/S0377-2217(96)00250-0

Cassel, C.; Hackl, P.; Westlund, A. H. 1999. Robustness of partial least-squares method for estimating latent variable quality structures, Journal of Applied Statistics 26(4): 435-446. http://dx.doi.org/10.1080/02664769922322

Chang, D. Y. 1996. Applications of the extent analysis method on fuzzy AHP, European Journal of Operational Research 95: 649-655. http://dx.doi.org/10.1016/0377-2217(95)00300-2

Cheng, M. Y.; Hsiang, C. C.; Tsai, H. C.; Do, H. L. 2011. Bidding decision making for construction company using a multi-criteria prospect model, Journal of Civil Engineering and Management 17(3): 424-436. http://dx.doi.org/10.3846/13923730.2011.598337

Choi, A.; Woo, W. 2011. Multiple-criteria decision making based on probabilistic estimation with contextual information for physiological signal monitoring, International Journal of Information Technology \& Decision Making 10(1): 109-120. http://dx.doi.org/10.1142/S0219622011004245

Davanzo, L. E.; Nesbitt, S. L. 1987. Performance fees for investment management, Financial Analysts Journal 43(1): 14-20. http://dx.doi.org/10.2469/faj.v43.n1.14

Dyer, R. F.; Forman, E. H. 1992. Group decision support with the analysis hierarchy process, Decision Support System 8: 99-124. http://dx.doi.org/10.1016/0167-9236(92)90003-8

Ergu, D.; Kou, G.; Peng, Y.; Shi, Y. 2011a. A simple method to improve the consistency ratio of the pairwise comparison matrix in ANP, European Journal of Operational Research 213(1): 246-259. http://dx.doi.org/10.1016/j.ejor.2011.03.014

Ergu, D.; Kou, G.; Shi, Y.; Shi, Y. 2011b. Analytic network process in risk assessment and decision analysis, Computers \& Operations Research. http://dx.doi.org/10.1016/j.cor.2011.03.005 
Ergu, D.; Kou, G.; Peng, Y.; Shi, Y.; Shi, Y. 2011c. The Analytic Hierarchy Process: task scheduling and resource allocation in cloud computing environment, The Journal of Supercomputing (in press). http://dx.doi.org/10.1007/s11227-011-0625-1

Fedrizzi, M.; Giove, S. 2007. Incomplete pair-wise comparison and consistency optimization, European Journal of Operational Research 183(1): 303-313. http://dx.doi.org/10.1016/j.ejor.2006.09.065

Fried, V. H.; Hisrich, R. D. 1994. Toward a model of venture capital investment decision making, Financial Management 23(3): 28-37. http://dx.doi.org/10.2307/3665619

Froot, K. A.; Scharfstein, D. S.; Stein, J. C. 1993. Risk management: coordinating corporate investment and financing policies, The Journal of Finance 48(5): 1629-1658. http://dx.doi.org/10.2307/2329062

Gao, Y.; Zhang, G. Q.; Lu, J.; Dillon, T.; Zeng, X. Y. 2008. A $\lambda$-cut approximate algorithm for goal-based bilevel risk management systems, International Journal of Information Technology \& Decision Making 7(4): 589-610. http://dx.doi.org/10.1142/S0219622008003113

Ginevičius, R.; Zubrecovas, V. 2009. Selection of the optimal real estate investment project basing on multiple criteria evaluation using stochastic dimensions, Journal of Business Economics and Management 10(3): 261-170. http://dx.doi.org/10.3846/1611-1699.2009.10.261-270

Handfield, R.; Walton, S. V.; Sroufe, R.; Melnyk, S. A. 2002. Applying environmental criteria to supplier assessment: a study in the application of the analytical hierarchy process, European Journal of Operational Research 141(1): 70-87 http://dx.doi.org/10.1016/S0377-2217(01)00261-2

Ishizaka, A.; Labib, A. 2011. Review of the main developments in the analytic hierarchy process, Expert Systems with Application 38(11): 14336-14345. http://dx.doi.org/10.1016/j.eswa.2011.04.143

Ishizaka, A.; Lusti, M. 2004. An expert module to improve the consistency of AHP matrices, International Transactions in Operational Research 11(1): 97-105. http://dx.doi.org/10.1111/j.1475-3995.2004.00443.x

Jorion, P. 2000. Risk management lessons from Long-term capital management, European Financial Management 6(3): 277-300. http://dx.doi.org/10.1111/1468-036X.00125

Kamal, M.; Al-Subhi, A. 2001. Application of the AHP in project management, International Journal of Project Management 19: 19-27. http://dx.doi.org/10.1016/S0263-7863(99)00038-1

Kent, D. M. 1992. A framework for integrated risk management in international business, Journal of International Business Studies 23(2): 311-331. http://dx.doi.org/10.1057/palgrave.jibs.8490270

Keršulienė, V.; Turskis, Z. 2011. Integrated fuzzy multiple criteria decision making model for architect selection, Technological and Economic Development of Economy 17(4): 645-666. http://dx.doi.org/10.3846/20294913.2011.635718

Kim, S. H.; Ahn, B. S. 1997. Group decision-making procedure considering preference strength under incomplete information, Computer \& Operations Research 24: 1101-1112. http://dx.doi.org/10.1016/S0305-0548(97)00037-3

Korpela, J.; Tuominen, M. 1995. Group decision support for defining the vision and strategic goals for distribution logistics, in Proceedings of the 28th Annual Hawaii International Conference on System Science, 189-215. http://doi.ieeecomputersociety.org/10.1109/HICSS.1995.375701

Korpela, J.; Tuominen, M. 1997. Group decision support for analyzing logistics development projects, in Proceedings of the 13th Hawaii International Conference, 493-502. http://dx.doi.org/10.1109/HICSS.1997.665652

Kou, G.; Lu, Y.; Peng, Y.; Shi, Y. 2012. Evaluation of classification algorithms using MCDM and rank correlation, International Journal of Information Technology \& Decision Making 11(1): 197-225. http://dx.doi.org/10.1142/S0219622012500095

Levary, R.; Wan, K. 1998. A simulation approach for handling uncertainty in the analytic hierarchy process, European Journal of Operations Research 106: 116-122. http://dx.doi.org/10.1016/S0377-2217(97)00134-3

Li, H.; Ma, L. 2008. Ranking decision alternatives by integrated DEA, AHP and Gower Plot Techniques, International Journal of Information Technology \& Decision Making 7(2): 241-258. http://dx.doi.org/10.1142/S0219622008002922 
Li, J.; Yu, L.; Jyrki, W. 2009. Guest editor's introduction: risk measurement and risk correlation analysis, International Journal of Information Technology \& Decision Making 8(4): 625-627. http://dx.doi.org/10.1142/S0219622009003739

Liaudanskienė, R.; Varnas, N.; Ustinovichius, L. 2010. Modeling the application of workplace safety and health act in Lithuanian construction sector, Technological and Economic Development of Economy 16(2): 233-253. http://dx.doi.org/10.3846/tede.2010.15

Lin, K. L. 2010. Determining key ecological indicators for urban land consolidation, International Journal of Strategic Property Management 14(2): 89-103. http://dx.doi.org/10.3846/ijspm.2010.08

Liu, D. R.; Shih, Y. Y. 2005. Integrating AHP and data mining for product recommendation based on customer lifetime value, Information and Management 42: 387-400. http://dx.doi.org/10.1016/j.im.2004.01.008

Liu, R.; Rallo, R.; Cohen, Y. 2011. Unsupervised feature selection using incremental least squares, International Journal of Information Technology \& Decision Making 10(6): 967-987. http://dx.doi.org/10.1142/S0219622011004671

Malkiel, B. G. 2003. Passive investment strategies and efficient markets, European Financial Management 9(1): 1-10. http://dx.doi.org/10.1111/1468-036X.00205

Medineckiene, M.; Björk, F. 2011. Owner preferences regarding renovation measures - the demonstration of using multi-criteria decision making, Journal of Civil Engineering and Management 17(2): 284-295. http://dx.doi.org/10.3846/13923730.2011.582380

Metrick, A. 1999. Performance evaluation with transactions data: the stock selection of investment newsletters, The Journal of Finance 54(5): 1743-1775. http://dx.doi.org/10.1111/0022-1082.00165

Nieto-Morote, A.; Ruz-Vila, F. 2011. A fuzzy AHP multi-criteria decision-making approach applied to combined cooling, heating, and power production systems, International Journal of Information Technology \& Decision Making 10(3): 497-517. http://dx.doi.org/10.1142/S0219622011004427

Peng, Y.; Kou, G.; Wang, G. X.; Wang, H. G.; Ko, F. I. S. 2009. Empirical evaluation of classifiers for software risk management, International Journal of Information Technology \& Decision Making 8(4): 749-767. http://dx.doi.org/10.1142/S0219622009003715

Peng, Y.; Wang, G.; Kou, G.; Shi, Y. 2010. An empirical study of classification algorithm evaluation in financial risk management, Applied Soft Computing 11(2): 2906-2915. http://dx.doi.org/10.1016/j.asoc.2010.11.028

Peng, Y.; Kou, G.; Wang, G.; Wu, W.; Shi, Y. 2011a. Ensemble of software defect predictors: an AHP-based evaluation method, International Journal of Information Technology \& Decision Making 10(1): 187-206. http://dx.doi.org/10.1142/S0219622011004282

Peng, Y.; Kou, G.; Wang, G.; Shi, Y. 2011b. FAMCDM: A fusion approach of MCDM methods to rank multiclass classification algorithms, Omega 39(6): 677-689. http://dx.doi.org/10.1016/j.omega.2011.01.009

Rao, C. J.; Peng, J. 2009. Fuzzy group decision making model based on credibility theory and gray relative degree, International Journal of Information Technology \& Decision Making 8(3): 515-527. http://dx.doi.org/10.1142/S0219622009003533

Saaty, T. L. 1978. Modeling unstructured decision problems-the theory of analytical hierarchies, Mathematics and Computers in Simulation 20(3): 147-158. http://dx.doi.org/10.1016/0378-4754(78)90064-2

Saaty, T. L. 1979. Applications of analytical hierarchies, Mathematics and Computers in Simulation 21: 1-20. http://dx.doi.org/10.1016/0378-4754(79)90101-0

Saaty, T. L. 1980. The Analytic Hierarchy Process. New York: McGraw-Hill. http://www.jstor.org/stable/25060854

Saaty, T. L. 1985. Decision Making for Leaders. California: Life Time Leaning Publications.

Saaty, T. L. 1986. Axiomatic foundation of the analytic hierarchy process, Management Science 32(7): 841-855. http://dx.doi.org/10.1287/mnsc.32.7.841 
Saaty, T. L. 1990. How to make a decision: the analytic hierarchy process, European Journal of Operational Research 48: 9-26. http://dx.doi.org/10.1016/0377-2217(90)90057-I

Saaty, T. L. 2003. Decision-making with the AHP: Why is the principal eigenvector necessary?, European Journal of Operational Research 145(1): 85-91. http://dx.doi.org/10.1016/S0377-2217(02)00227-8

Saaty, T. L. 2006. The analytic network process, decision making with the analytic network process, International Series in Operations Research and Management Science 95: 1-26. http://dx.doi.org/10.1007/0-387-33987-6_1

Saaty, T. L.; Zoffer, H. J. 2011. Negotiating the Israeli-Palestinian controversy from a new perspective, International Journal of Information Technology \& Decision Making 10(1): 5-64. http://dx.doi.org/10.1142/S021962201100421X

Shen, C. 2009. A bayesian networks approach to modeling financial risks of E-Logistics investments, International Journal of Information Technology \& Decision Making 8(4): 711-726. http://dx.doi.org/10.1142/S0219622009003594

Shyng, J.; Shieh, H.; Tzeng, G.; Hsieh, S. 2010. Using FSBT technique with rough set theory for personal investment portfolio analysis, European Journal of Operational Research 201(2): 601-607. http://dx.doi.org/10.1016/j.ejor.2009.03.031

Soylu, B. 2010. Integrating PROMETHEE II with the Tchebycheff function for multi criteria decision making, International Journal of Information Technology \& Decision Making 9(4): 525-545. http://dx.doi.org/10.1142/S0219622010003944

Stoughton, N. M.; Wu, Y. C.; Zechner, J. 2011. Intermediated investment management, The Journal of Finance 66(3): 947-980. http://dx.doi.org/10.1111/j.1540-6261.2011.01656.x

Teichroew, D.; Robichek, A. A.; Montalbano, M. 1965. An analysis of criteria for investment and financing decisions under certainty, Management Science 12(3): 151-179.

http://dx.doi.org/10.1287/mnsc.12.3.151

Tupenaite, L.; Zavadskas, E. K.; Kaklauskas, A.; Turskis, Z.; Seniut, M. 2010. Multiple criteria assessment of alternatives for built and human environment renovation, Journal of Civil Engineering and Management 16(2): 257-266. http://dx.doi.org/10.3846/jcem.2010.30

Wei, C.; Tang, X. 2011. An intuitionistic fuzzy group decision-making approach based on entropy and similarity measures, International Journal of Information Technology \& Decision Making 10(6): 1111-1130. http://dx.doi.org/10.1142/S0219622011004737

Wijnmalen, D. 2007. Analysis of benefits, opportunities, costs, and risks (BOCR) with the AHP-ANP: a critical validation, Mathematical and Computer Modeling 46: 892-905. http://dx.doi.org/10.1016/j.mcm.2007.03.020.

Wind, Y.; Saaty, T. L. 1980. Marketing applications of the analytic hierarchy process, Management Science 26(7): 641-658. http://dx.doi.org/10.1287/mnsc.26.7.641

Wu, L.; Cui, X.; Dai, R. 2010. Judgment number reduction: an issue in the Analytic Hierarchy Process, International Journal of Information Technology \& Decision Making 9(1): 175-189. http://dx.doi.org/10.1142/S0219622010003683

Wu, W.; Kou, G.; Peng, Y.; Shi, Y. 2011. Group decision support for credit risk evaluation with improved MCDM model, Submit to Expert System with Application.

Yu, C. S. 2002. A GP-AHP method for solving group decision-making fuzzy AHP problems, Computers and Operations Research 29: 1969-2001. http://dx.doi.org/10.1016/S0305-0548(01)00068-5

Yu, L.; Wang, S.; Cao, J. 2009. A modified least squares support vector machine classifier with application to credit risk analysis, International Journal of Information Technology \& Decision Making 8(4): 697-710. http://dx.doi.org/10.1142/S0219622009003600

Zavadskas, E. K.; Turskis, Z.; Tamošaitiene, J. 2010. Risk assessment of construction projects, Journal of Civil Engineering and Management 16(1): 33-46. http://dx.doi.org/10.3846/jcem.2010.03 


\section{Appendix}

Table 1. B-A level comparison matrix of five experts

\begin{tabular}{ccc}
\hline B-A & Profitability: B1 & Security: B2 \\
\hline Expert 1 & 8 & 6 \\
\hline Expert 2 & 7 & 7 \\
\hline Expert 3 & 5 & 7 \\
\hline Expert 4 & 7 & 4 \\
\hline Expert 5 & 3 & 7 \\
\hline
\end{tabular}

Table 2. C-B1 level comparison matrix of five experts

\begin{tabular}{ccccc}
\hline C-B1 & $\begin{array}{c}\text { Investment } \\
\text { opportunities: C1 }\end{array}$ & Liquidity: C2 & Prospect: C3 & $\begin{array}{c}\text { Expected } \\
\text { profit: C4 }\end{array}$ \\
\hline Expert 1 & 8 & 7 & 7 & 6 \\
\hline Expert 2 & 5 & 6 & 5 & 7 \\
\hline Expert 3 & 6 & 5 & 7 & 8 \\
\hline Expert 4 & 9 & 8 & 7 & 5 \\
\hline Expert 5 & 4 & 6 & 5 & 8 \\
\hline
\end{tabular}

Table 3. C-B2 level comparison matrix of five experts

\begin{tabular}{ccccc}
\hline C-B2 & Payback period: C5 & $\begin{array}{c}\text { Transaction } \\
\text { costs: C6 }\end{array}$ & $\begin{array}{c}\text { Interest rate } \\
\text { risk: C7 }\end{array}$ & $\begin{array}{c}\text { Credit risk: } \\
\text { C8 }\end{array}$ \\
\hline Expert 1 & 5 & 7 & 9 & 8 \\
\hline Expert 2 & 6 & 7 & 7 & 8 \\
\hline Expert 3 & 8 & 6 & 6 & 8 \\
\hline Expert 4 & 4 & 6 & 9 & 7 \\
\hline Expert 5 & 7 & 6 & 5 & 8 \\
\hline
\end{tabular}

Table 4. D-C1 level comparison matrix of five experts

\begin{tabular}{ccccc}
\hline D-C1 & $\begin{array}{c}\text { Fund } \\
\text { Investment }\end{array}$ & $\begin{array}{c}\text { Bonds } \\
\text { Investment }\end{array}$ & $\begin{array}{c}\text { Stock } \\
\text { Investment }\end{array}$ & $\begin{array}{c}\text { Real Estate } \\
\text { Investment }\end{array}$ \\
\hline Expert 1 & 5 & 3 & 8 & 7 \\
\hline Expert 2 & 7 & 6 & 7 & 8 \\
\hline Expert 3 & 6 & 7 & 3 & 5 \\
\hline Expert 4 & 4 & 2 & 8 & 7 \\
\hline Expert 5 & 7 & 8 & 4 & 7 \\
\hline
\end{tabular}

Table 5. D-C2 level comparison matrix of five experts

\begin{tabular}{ccccc}
\hline D-C2 & $\begin{array}{c}\text { Fund } \\
\text { Investment }\end{array}$ & $\begin{array}{c}\text { Bonds } \\
\text { Investment }\end{array}$ & $\begin{array}{c}\text { Stock } \\
\text { Investment }\end{array}$ & $\begin{array}{c}\text { Real Estate } \\
\text { Investment }\end{array}$ \\
\hline Expert 1 & 7 & 6 & 9 & 7 \\
\hline Expert 2 & 7 & 3 & 6 & 8 \\
\hline Expert 3 & 7 & 8 & 3 & 5 \\
\hline Expert 4 & 4 & 3 & 8 & 6 \\
\hline Expert 5 & 5 & 6 & 4 & 8 \\
\hline
\end{tabular}


Table 6. D-C3 level comparison matrix of five experts

\begin{tabular}{ccccc}
\hline D-C3 & $\begin{array}{c}\text { Fund } \\
\text { Investment }\end{array}$ & $\begin{array}{c}\text { Bonds } \\
\text { Investment }\end{array}$ & $\begin{array}{c}\text { Stock } \\
\text { Investment }\end{array}$ & $\begin{array}{c}\text { Real Estate } \\
\text { Investment }\end{array}$ \\
\hline Expert 1 & 6 & 7 & 4 & 8 \\
\hline Expert 2 & 7 & 4 & 5 & 9 \\
\hline Expert 3 & 4 & 7 & 3 & 7 \\
\hline Expert 4 & 5 & 2 & 8 & 8 \\
\hline Expert 5 & 4 & 5 & 7 & \\
\hline
\end{tabular}

Table 7. D-C4 level comparison matrix of five experts

\begin{tabular}{ccccc}
\hline D-C4 & $\begin{array}{c}\text { Fund } \\
\text { Investment }\end{array}$ & $\begin{array}{c}\text { Bonds } \\
\text { Investment }\end{array}$ & $\begin{array}{c}\text { Stock } \\
\text { Investment }\end{array}$ & $\begin{array}{c}\text { Real Estate } \\
\text { Investment }\end{array}$ \\
\hline Expert 1 & 6 & 3 & 8 & 5 \\
\hline Expert 2 & 6 & 4 & 6 & 8 \\
\hline Expert 3 & 6 & 5 & 7 & 4 \\
\hline Expert 4 & 5 & 3 & 9 & 7 \\
\hline Expert 5 & 4 & 6 & 7 & 9 \\
\hline
\end{tabular}

Table 8. D-C5 level comparison matrix of five experts

\begin{tabular}{ccccc}
\hline D-C5 & $\begin{array}{c}\text { Fund } \\
\text { Investment }\end{array}$ & $\begin{array}{c}\text { Bonds } \\
\text { Investment }\end{array}$ & $\begin{array}{c}\text { Stock } \\
\text { Investment }\end{array}$ & $\begin{array}{c}\text { Real Estate } \\
\text { Investment }\end{array}$ \\
\hline Expert 1 & 4 & 8 & 2 & 7 \\
\hline Expert 2 & 8 & 5 & 7 & 7 \\
\hline Expert 3 & 6 & 6 & 8 & 7 \\
\hline Expert 4 & 7 & 3 & 9 & 8 \\
\hline Expert 5 & 5 & 6 & 8 & 9 \\
\hline
\end{tabular}

Table 9. D-C6 level comparison matrix of five experts

\begin{tabular}{ccccc}
\hline D-C6 & $\begin{array}{c}\text { Fund } \\
\text { Investment }\end{array}$ & $\begin{array}{c}\text { Bonds } \\
\text { Investment }\end{array}$ & $\begin{array}{c}\text { Stock } \\
\text { Investment }\end{array}$ & $\begin{array}{c}\text { Real Estate } \\
\text { Investment }\end{array}$ \\
\hline Expert 1 & 7 & 8 & 7 & 4 \\
\hline Expert 2 & 7 & 6 & 7 & 8 \\
\hline Expert 3 & 6 & 7 & 5 & 6 \\
\hline Expert 4 & 7 & 6 & 9 & 8 \\
\hline Expert 5 & 7 & 6 & 4 & 8 \\
\hline
\end{tabular}

Table 10. D-C7 level comparison matrix of five experts

\begin{tabular}{ccccc}
\hline D-C7 & $\begin{array}{c}\text { Fund } \\
\text { Investment }\end{array}$ & $\begin{array}{c}\text { Bonds } \\
\text { Investment }\end{array}$ & $\begin{array}{c}\text { Stock } \\
\text { Investment }\end{array}$ & $\begin{array}{c}\text { Real Estate } \\
\text { Investment }\end{array}$ \\
\hline Expert 1 & 4 & 2 & 3 & 5 \\
\hline Expert 2 & 6 & 7 & 7 & 7 \\
\hline Expert 3 & 6 & 8 & 5 & 6 \\
\hline Expert 4 & 5 & 4 & 8 & 6 \\
\hline Expert 5 & 3 & 5 & 8 & 6 \\
\hline
\end{tabular}


Table 11. D-C8 level comparison matrix of five experts

\begin{tabular}{ccccc}
\hline D-C8 & $\begin{array}{c}\text { Fund } \\
\text { Investment }\end{array}$ & $\begin{array}{c}\text { Bonds } \\
\text { Investment }\end{array}$ & $\begin{array}{c}\text { Stock } \\
\text { Investment }\end{array}$ & $\begin{array}{c}\text { Real Estate } \\
\text { Investment }\end{array}$ \\
\hline Expert 1 & 4 & 2 & 7 & 5 \\
\hline Expert 2 & 5 & 8 & 7 & 6 \\
\hline Expert 3 & 6 & 7 & 4 & 5 \\
\hline Expert 4 & 5 & 3 & 8 & 7 \\
\hline Expert 5 & 4 & 4 & 2 & 6 \\
\hline
\end{tabular}

Wenshuai WU is a doctoral student in School of Management and Economics, University of Electronic Science and Technology of China. His research interests are in Multiple Criteria Decision Making. He has published more than ten papers in international journals and conferences.

Gang KOU is a professor of School of Management and Economics, University of Electronic Science and Technology of China and managing editor of International Journal of Information Technology \& Decision Making. Previously, he was a research scientist in Thomson Co., R\&D. He received his Ph.D. in Information Technology from the College of Information Science \& Technology, University of Nebraska at Omaha; got his Master degree in Department of Computer Science, University of Nebraska at Omaha; and B.S. degree in Department of Physics, Tsinghua University, Beijing, China. He has participated in various data mining projects, including data mining for software engineering, network intrusion detection, health insurance fraud detection and credit card portfolio analysis. His research interests are in Data mining, Multiple Criteria Decision Making and Information management. He has published more than eighty papers in various peer-reviewed journals and conferences.

Yi PENG is a professor of School of Management and Economics, University of Electronic Science and Technology of China. Previously, she worked as Senior Analyst for West Co., USA. Dr. Peng received her Ph.D. in Information Technology from the College of Information Science \& Technology, Univ. of Nebraska at Omaha and got her Master degree in Dept of Info. Science \& Quality Assurance, Univ. of Nebraska at Omaha and B.S. degree in Department of Management Information Systems, Sichuan University, China. Dr. Peng's research interests cover Knowledge Discover in Database and data mining, multi-criteria decision making, data mining methods and modeling, knowledge discovery in real-life applications. She published more than forty papers in various peer-reviewed journals and conferences. She is the Workshop Chair of the 20th International Conference on Multiple Criteria Decision Making (2009), guest editor of Annals of Operations Research's special issue on Multiple Criteria Decision Making on Operations Research.

Daji ERGU got his M.S. degrees in Southwest University for Nationalities and Coventry University in 2003 and 2004 respectively. He is an associate professor at Southwest University for Nationalities. He has participated in several research projects of National Natural Science Foundation of China. His research interests are in Multiple Criteria Decision Making. He has published more than ten papers in international journals and conferences. 